\title{
Health and Safety Challenges on South African Regional Public Sector Projects
}

\author{
Nomakhwezi Mafuya $^{1}$ and John Smallwood ${ }^{2}$
}

1 Nelson Mandela University, Port Elizabeth, South Africa, nomakhwezi_mafuya@yahoo.com;

2 Nelson Mandela University, Port Elizabeth, South Africa, john.smallwood@mandela.ac.za

\begin{abstract}
The South African construction industry has a poor health and safety (H\&S) record, and continues to be noted for H\&S non-compliance, injuries, and fatalities.

The aim of the study reported on was to evolve a strategy to mitigate H\&S non-compliance, injuries including fatalities, design originated hazards, and recurring H\&S problems experienced on a provincial Department of Public Works' (DPW) projects.

The study adopted a quantitative approach and focused on seven school construction projects, and included, inter alia, construction project managers (CPMs) based in the provincial DPWs' project management department that were involved with the projects. The CPMs were surveyed using a selfadministered questionnaire.

The study determined that inadequate H\&S knowledge and awareness, inadequate H\&S management and supervision on site, inadequate worker participation, inadequate H\&S training, inadequate designer 'report', negligence, unsafe acts and conditions, H\&S non-compliance, inadequate Safe Operating Procedures (SOPs) and Safe Working Procedures (SWPs), inadequate commitment of various project stakeholders, ignorance, and poor client H\&S leadership are the primary causes of H\&S non-compliance, injuries including fatalities, design originated hazards, and recurring H\&S problems.
\end{abstract}

Recommendations include: H\&S must be included as a project value; H\&S must be integrated within the Department's internal project systems from project inception to project close out, and all stakeholders' H\&S competencies must be enhanced.

(C) 2020 The Authors. Published by Budapest University of Technology and Economics \& Diamond Congress Ltd Peer-review under responsibility of the Scientific Committee of the Creative Construction Conference 2020.

Keywords: clients, health and safety, practices, value

\section{Introduction}

The considerable number of accidents, fatalities, and other injuries that occur in the South African construction industry are highlighted in the 'Construction Health \& Safety Status \& Recommendations' report [1]. The report cited the high-level of non-compliance with $\mathrm{H} \& \mathrm{~S}$ legislative requirements, which is indicative of a deficiency of effective management and supervision of H\&S on construction sites as well as planning from the inception / conception of projects within the context of project management. The report also cited a lack of sufficiently skilled, experienced, and knowledgeable persons to manage H\&S on construction sites.

Given the differing interpretation of project management globally, it is important to define it within the context of South Africa, namely: "Construction project management is the management of projects within 
the built environment from conception to completion, including management of related professional services, and the construction project manager is the one point of responsibility in this regard." [2] Therefore, construction project managers (CPMs) coordinate and manage design delivery, manage the procurement process, integrate the design, procurement, and construction processes, and monitor the construction process.

The Construction Regulations, which constitute the primary regulations in terms of managing $\mathrm{H} \& \mathrm{~S}$ in the South African construction industry, allocate a range of H\&S responsibilities to clients, designers, quantity surveyors, principal contractors, and contractors [3]. Given the definition of construction project management and the requirements arising from the Construction Regulations, CPMs must ensure that H\&S is integrated into the six stages of projects. Furthermore, integration implies that CPMs must ensure that $\mathrm{H} \& \mathrm{~S}$ is a 'value' during projects.

Given the status of H\&S in South African construction, the requirements of H\&S legislation, the functions of CPMs, and the status of H\&S on a provincial Department of Public Works' (DPW) projects, a study was conducted among the department's CPMs, the objectives being to determine the:

- extent to which a range of thirteen factors contribute to recurring H\&S problems in construction;

- respondents self-rating of their knowledge regarding eight project management of H\&S aspects;

- extent to which sixteen factors contribute to design originated hazards;

- extent to which ten factors contribute to exposure to hazards on construction sites, and

- frequency at which twenty-four factors are the cause of construction accidents.

\section{Review of the literature}

\subsection{Compliance and non-compliance}

The Department of Labour inspectorate conducted inspections throughout South Africa in August 2007 [1]. $52.5 \%$ of the contractors were found to be non-compliant with the Occupational Health \& Safety Act and the Construction Regulations on the 1415 construction sites visited. Of the 1388 notices issued by inspectors, 86 (6\%) were improvement notices, 1015 (73\%) were contravention, and 287 (21\%) were prohibition. These findings indicate contractors in general are not complying, and underscore the rationale for client responsibility for construction H\&S in terms of the Construction Regulations, and the need for CPMs to integrate construction H\&S into the six stages of projects.

\subsection{Health and safety legislation}

In terms of the South African Construction Regulations [3], clients are required to, inter alia, prepare an H\&S specification based on their baseline risk assessment (BRA), which is then provided to designers. Designers in turn are required to, inter alia: consider the H\&S specification; submit a report to the client before tender stage that includes all the relevant H\&S information about the design that may affect the pricing of the work, the geotechnical-science aspects, and the loading that the structure is designed to withstand; inform the client of any known or anticipated dangers or hazards relating to the construction work, and make available all relevant information required for the safe execution of the work upon being designed or when the design is changed; modify the design or make use of substitute materials where the design necessitates the use of dangerous procedures or materials hazardous to H\&S, and consider hazards relating to subsequent maintenance of the structure and make provision in the design for that work to be performed to minimise the risk. To mitigate design originated hazards, requires hazard identification and risk assessment (HIRA) and appropriate responses, which process should be structured and documented.

Thereafter, clients must include the H\&S specification in the tender documentation, which in theory should have been revised to include any relevant $\mathrm{H} \& \mathrm{~S}$ information included in the designer report. Thereafter, they must, inter alia: ensure that potential principal contractors (PCS) have made provision for the cost of H\&S in their tenders; ensure that the PC to be appointed has the necessary competencies and resources; ensure that every PC is registered for workers' compensation insurance cover and in good standing; discuss and negotiate with the PC the contents of the PC's H\&S plan and thereafter approve it; take reasonable steps to 
ensure that each contractor's H\&S plan is implemented and maintained; ensure that periodic H\&S audits and documentation verification are conducted at agreed intervals, but at least once every 30 days; ensure that the H\&S file is kept and maintained by the PC, and appoint a competent person in writing as an agent when a construction work permit is required. To mitigate design originated hazards, requires HIRA and appropriate responses, which process should be structured and documented.

\subsection{The role of project managers}

The Australian Federal Safety Commissioner's best practice client H\&S principles emphasise, inter alia, the inclusion of H\&S as an integral aspect of project management, and that H\&S should be afforded status equal to that afforded cost, quality, and time [4].

A previous study conducted among CPMs in South Africa determined that they frequently consider / refer to H\&S on fourteen occasions, as opposed to infrequently. However, they do so more frequently during the downstream and midstream stages than the upstream stages of projects. Downstream occasions include site inspections / discussions, site meetings, and site handover; and midstream occasions include preparing project documentation, evaluating tenders, pre-tender meeting, and pre-qualifying contractors. Furthermore, they consider / refer to sixteen design related aspects frequently as opposed to infrequently - method of fixing, position of components, specification, type of structural frame, and site location predominate [5].

\subsection{Contributing factors in accidents}

A study conducted by Haslam, Hide, Gibb, Gyi, Pavitt, Atkinson, \& Duff [6] reviewed 100 accidents.

The first category includes 'immediate accident circumstances and shaping factors'. Problems arising from workers, which includes all site-based personnel, or the work team, especially worker actions or behaviour and worker capabilities, were judged to have been involved in over $70 \%$ of the accidents. Workplace factors, most notably poor housekeeping and problems with the site layout and space availability, were considered to have contributed $49 \%$ of the accident studies. Local hazards on site were a feature in many of the 100 accidents reviewed. Shortcomings with equipment, including personal protective equipment (PPE), were identified in $56 \%$ of the incidents. Deficiencies with the suitability and condition of materials, including packaging, featured in $27 \%$ of incidents.

The second category are 'originating influences', in which case inadequacies with risk management were considered to have been present in $94 \%$ of the accidents. In terms of 'construction design and processes', Haslam et al. state that the elimination or reduction of risks through design or alternative methods of construction is highly desirable. In terms of 'project management', a clear influence from problems with project management was identified in only a quarter of the accident studies, although this is likely to have been because the precise effects are difficult to corroborate. In terms of 'risk management' deficiencies related thereto were identified in most of the 100 accidents studied. Acci- dents invariably involve an inadequately controlled risk, which is indicative of a management failing. In terms of 'client and economic influences', there was limited direct evidence of the influence of client requirements or the economic climate on the accidents studied, although they undoubtedly do affect construction H\&S. In terms of 'H\&S education and training', the explanations from the accident study interviews and focus groups for construction workers engaging in unsafe acts were three-fold: H\&S being overlooked in the context of heavy workloads and other priorities; taking shortcuts to save effort and time, and inaccurate perception of risk. Underlying each of these are inadequate H\&S knowledge, which indicates deficiencies with H\&S education and training. A further issue is the inadequacy of university construction-related courses in terms of $\mathrm{H} \& \mathrm{~S}$ education.

\section{Research}

\subsection{Research method and sample stratum}

The study adopted a quantitative approach and focused on seven school construction projects, and included, inter alia, forty construction project managers (CPMs) based in the provincial DPWs' project 
management department that were involved with the projects. The CPMs were surveyed using a selfadministered questionnaire. The questionnaire consisted of eleven questions, six of which were closedended, and five open-ended. The six closed-ended questions were five- or six-point Likert scale-type questions. A further seven questions were included in an addendum, which were closed-ended and were five- or six-point Likert scale-type questions. Thirty-nine responses were received and included in the analysis of the data, which equates to a response rate of $97.5 \%$. The analysis of the data entailed the computation of descriptive statistics in the form of frequencies and a measure of central tendency in the form of a mean score (MS).

\subsection{Research findings}

97.4\% of respondents have worked for their current employer $>1$ year, $58.9 \%$ for $>5$ years, and $25.6 \%>10$ years. The mean length of time respondents had worked for their current employer is 9.6 years. $100 \%$ of respondents have worked in construction for $>1$ year, $71.8 \%$ for $>5$ years, and $41 \%>10$ years. The mean length of time respondents had worked in construction is 13.7 years. Therefore, the respondents can be deemed experienced, which contributes to the reliability of the findings.

$56.4 \%$ of respondents were ' $\leq 40$ ' years of age, and $43.5 \%$ were $>40$ years. Per definition relative to workers, people $>40$ years of age are 'older workers'. The mean age was 40 years. $33.3 \%$ of respondents were female, and $66.7 \%$ were male. In terms of qualifications, $84.6 \%$ of the respondents have a National Diploma or higher qualification.

Table 1 indicates the extent to which factors contribute to recurring H\&S problems in construction in terms of percentage responses to a scale of 1 (minor) to 5 (major), and a MS ranging between 1.00 and 5.00.

It is notable that all the MSs are above the midpoint score of 3.00, which indicates that in general the respondents can be deemed to perceive the factors contribute to recurring H\&S problems in construction to more of a major than a minor extent. It is notable that no factors' MSs are $>4.20 \leq 5.00$ - between a near major to major / major extent.

All the MSs are $>3.40 \leq 4.20$, which indicates the respondents perceive the factors contribute to recurring $\mathrm{H} \& \mathrm{~S}$ problems in construction between some extent to a near major extent / near major extent.

'Poor client H\&S leadership' is the only factor that has a MS $>3.80 \leq 4.20$, which falls within the upper part of the range. This is notable as it is client related, and the Construction Regulations schedule a range of requirements for clients. This is followed by 'inadequate construction H\&S planning', which indicates the role of sound construction management in the form of planning. This in turn is followed by 'insufficient $\mathrm{H} \& \mathrm{~S}$ skills', 'inadequate construction management commitment to H\&S', 'inadequate financial provision for $\mathrm{H} \& \mathrm{~S}$ in the BoQ', 'inadequate construction manager H\&S knowledge', 'inadequate construction manager $\mathrm{H} \& \mathrm{~S}$ experience', 'inadequate construction management involvement in $\mathrm{H} \& \mathrm{~S}^{\prime}$, and 'inadequate construction management participation in $H \& S^{\prime}$, which are all H\&S related. These findings highlight the importance of construction management involvement and participation in $\mathrm{H} \& \mathrm{~S}$ in addition to construction management commitment to H\&S. 'Non-integration of H\&S into projects during the planning stages', 'inadequate design for construction $\mathrm{H} \& \mathrm{~S}^{\prime}$, and 'insufficient $\mathrm{H} \& \mathrm{~S}$ communication amongst stakeholders' amplify the multistakeholder nature of H\&S. Last ranked 'inadequate top management support' yet again amplifies the importance of management. 
Table 1. Extent to which factors contribute to recurring H\&S problems in construction.

\begin{tabular}{|c|c|c|c|c|c|c|c|c|}
\hline \multirow{3}{*}{ Factor } & \multicolumn{6}{|c|}{ Response (\%) } & \multirow{3}{*}{ MS } & \multirow{3}{*}{ Rank } \\
\hline & \multirow{2}{*}{$\begin{array}{l}\text { Un- } \\
\text { sure }\end{array}$} & \multicolumn{4}{|c|}{ Minor.. } & \multirow{2}{*}{ Major } & & \\
\hline & & 1 & 2 & 3 & 4 & & & \\
\hline Poor client H\&S leadership & 7.7 & 2.6 & 10.3 & 17.9 & 30.8 & 30.8 & 3.83 & 1 \\
\hline Inadequate construction $\mathrm{H} \& \mathrm{~S}$ planning & 5.1 & 5.1 & 10.3 & 23.1 & 23.1 & 33.3 & 3.73 & 2 \\
\hline Insufficient H\&S skills & 0.0 & 5.1 & 10.3 & 30.8 & 17.9 & 35.9 & 3.69 & 3 \\
\hline Inadequate construction management commitment to $\mathrm{H} \& \mathrm{~S}$ & 0.0 & 5.3 & 2.6 & 28.9 & 44.7 & 18.4 & 3.68 & 4 \\
\hline Inadequate financial provision for $\mathrm{H} \& \mathrm{~S}$ in the $\mathrm{BoQ}$ & 0.0 & 7.7 & 15.4 & 12.8 & 30.8 & 33.3 & 3.67 & 5 \\
\hline Inadequate construction manager $\mathrm{H} \& \mathrm{~S}$ knowledge & 0.0 & 5.1 & 10.3 & 28.2 & 25.6 & 30.8 & 3.67 & 6 \\
\hline Inadequate construction manager H\&S experience & 0.0 & 10.3 & 5.1 & 23.1 & 33.3 & 28.2 & 3.64 & 7 \\
\hline Inadequate construction management involvement in $\mathrm{H} \& \mathrm{~S}$ & 0.0 & 5.3 & 7.9 & 26.3 & 42.1 & 18.4 & 3.61 & 8 \\
\hline Inadequate construction management participation in $\mathrm{H} \& \mathrm{~S}$ & 0.0 & 5.3 & 5.3 & 31.6 & 42.1 & 15.8 & 3.58 & 9 \\
\hline $\begin{array}{l}\text { Non-integration of } \mathrm{H} \& \mathrm{~S} \text { into projects during the planning } \\
\text { stages }\end{array}$ & 2.6 & 10.3 & 7.7 & 25.9 & 23.1 & 30.8 & 3.58 & 10 \\
\hline Inadequate design for construction $\mathrm{H} \& \mathrm{~S}$ & 2.6 & 7.7 & 2.6 & 38.5 & 25.6 & 23.1 & 3.55 & 11 \\
\hline Insufficient H\&S communication amongst stakeholders & 7.9 & 5.3 & 5.3 & 39.5 & 18.4 & 23.7 & 3.54 & 12 \\
\hline Inadequate top management support & 5.1 & 5.1 & 17.9 & 20.5 & 23.1 & 28.2 & 3.54 & 13 \\
\hline
\end{tabular}

Table 2 indicates the respondents' rating of their knowledge regarding various project management of $\mathrm{H} \& \mathrm{~S}$ aspects in terms of percentage responses to a scale of 1 (limited) to 5 (extensive), and a MS ranging between 1.00 and 5.00 .

It is notable that all the MSs are below the midpoint score of 3.00, which indicates that in general the respondent's rate their knowledge regarding various project management of H\&S aspects as below average.

$7 / 8$ (87.5\%) MSs are $>2.60 \leq 3.40$, which indicates the respondents rate their knowledge regarding various project management of H\&S aspects aspects as below average to average / average. 'Identifying design originated hazards' is ranked first, followed closely by 'risk management, 'constructability reviews', 'implementing H\&S systems at client level', 'baseline risk assessment (BRA)', 'project managing construction $\mathrm{H} \& \mathrm{~S}^{\prime}$, and 'designing for construction $\mathrm{H} \& \mathrm{~S}^{\prime}$. All eights aspects are important in terms of project managing construction $\mathrm{H} \& \mathrm{~S}$, and it is notable that given the function of the respondents, the latter is ranked sixth.

The MS of last ranked 'design hazard identification and risk assessments (HIRAs)' is $>1.80 \leq 2.60$, which indicates that the respondents rate their knowledge regarding this aspect as limited to below average $/$ below average. This is notable as design HIRAs are a key intervention in terms of 'designing for construction $H \& S^{\prime}$.

Table 2. Respondents rating of their knowledge regarding various project management of H\&S aspects.

\begin{tabular}{|c|c|c|c|c|c|c|c|c|}
\hline \multirow{3}{*}{ Aspect } & \multicolumn{6}{|c|}{ Response (\%) } & \multirow{3}{*}{ MS } & \multirow{3}{*}{ Rank } \\
\hline & \multirow{2}{*}{$\begin{array}{l}\text { Un- } \\
\text { sure }\end{array}$} & \multicolumn{3}{|c|}{ Limited. } & \multicolumn{2}{|c|}{ Extensive } & & \\
\hline & & 1 & 2 & 3 & 4 & 5 & & \\
\hline Identifying design originated hazards & 2.6 & 13.2 & 23.7 & 21.1 & 34.2 & 5.3 & 2.95 & 1 \\
\hline Risk management & 0.0 & 18.9 & 10.8 & 35.1 & 32.4 & 2.7 & 2.89 & 2 \\
\hline Constructability reviews & 8.6 & 8.6 & 25.7 & 31.4 & 22.9 & 2.9 & 2.84 & 3 \\
\hline Implementing H\&S systems at client level & 2.7 & 13.5 & 16.2 & 45.9 & 18.9 & 2.7 & 2.81 & 4 \\
\hline Baseline Risk Assessment (BRA) & 10.5 & 13.2 & 18.4 & 36.8 & 15.8 & 5.3 & 2.79 & 5 \\
\hline Project managing construction $\mathrm{H} \& \mathrm{~S}$ & 0.0 & 13.5 & 29.7 & 35.1 & 13.5 & 8.1 & 2.73 & 6 \\
\hline Designing for construction H\&S & 7.9 & 10.5 & 28.9 & 34.2 & 13.2 & 5.3 & 2.71 & 7 \\
\hline Design HIRAs & 7.9 & 15.8 & 36.8 & 21.1 & 15.8 & 2.6 & 2.49 & 8 \\
\hline
\end{tabular}

Table 3 indicates the extent to which factors contribute to design originated hazards in terms of percentage responses to a scale of 1 (minor) to 5 (major), and a MS ranging between 1.00 and 5.00 . 
It is notable that all the MSs are above the midpoint score of 3.00, which indicates that in general the respondents can be deemed to perceive the factors contribute to design originated hazards to more of a major than a minor extent.

It is notable that the top ranked factor 'inadequate H\&S consultants' construction expertise in terms of the management of H\&S' has a MS $>4.20 \leq 5.00$, which indicates it is deemed to contribute between a near major extent to a major / major extent to design originated hazards.

13 / 16 (81.3\%) MSs are $>3.40 \leq 4.20$, which indicates that the factors are deemed to make between a contribution to a near major / near major contribution to design originated hazards. The MSs of the factors ranked second to seventh fall within the upper part of the range, namely $>3.80 \leq 4.20$. These include 'inadequate departmental H\&S personnel's construction expertise in terms of the management of $H_{\&} S^{\prime}$ ', 'inadequate designer report', 'inadequate H\&S consultants' H\&S knowledge of construction activities', 'failure to appoint CHSA at Stage 1', inadequate design HIRAs', and 'project design and inputs are incomplete when construction commences'.

The factors ranked fifteenth and sixteenth have MSs $>2.60 \leq 3.40$, which indicates that they are deemed to make between a near minor contribution to contribution / contribution to design originated hazards 'inadequate top management H\&S knowledge of construction activities', and 'client initiated variations'.

Table 3. Extent to which factors contribute to design originated hazards.

\begin{tabular}{|c|c|c|c|c|c|c|c|c|}
\hline \multirow{3}{*}{ Factor } & \multicolumn{6}{|c|}{ Response (\%) } & \multirow{3}{*}{ MS } & \multirow{3}{*}{ Rank } \\
\hline & \multirow{2}{*}{$\begin{array}{l}\text { Un- } \\
\text { sure }\end{array}$} & \multicolumn{4}{|c|}{ Minor.. } & \multirow{2}{*}{$\frac{\text { Major }}{5}$} & & \\
\hline & & 1 & 2 & 3 & 4 & & & \\
\hline $\begin{array}{l}\text { Inadequate H\&S consultants' construction expertise in } \\
\text { terms of the management of } \mathrm{H} \& S\end{array}$ & 10.5 & 2.6 & 2.6 & 13.2 & 21.1 & 50.0 & 4.26 & 1 \\
\hline $\begin{array}{l}\text { Inadequate departmental H\&S personnel's construction } \\
\text { expertise in terms of the management of H\&S }\end{array}$ & 7.9 & 2.6 & 7.9 & 15.8 & 23.7 & 42.1 & 4.03 & 2 \\
\hline Inadequate designer report & 10.8 & 2.7 & 5.4 & 24.3 & 21.6 & 35.1 & 3.91 & 3 \\
\hline $\begin{array}{l}\text { Inadequate H\&S consultants' H\&S knowledge of } \\
\text { construction activities }\end{array}$ & 10.3 & 5.1 & 2.6 & 28.2 & 15.4 & 38.5 & 3.89 & 4 \\
\hline Failure to appoint CHSA at Stage 1 & 10.5 & 5.3 & 5.3 & 18.4 & 26.3 & 34.2 & 3.88 & 5 \\
\hline Inadequate design HIRAs & 15.4 & 0.0 & 5.1 & 30.8 & 20.5 & 28.2 & 3.85 & 6 \\
\hline $\begin{array}{l}\text { Project design and inputs are incomplete when } \\
\text { construction commences }\end{array}$ & 5.1 & 2.6 & 7.7 & 30.8 & 15.4 & 38.5 & 3.84 & 7 \\
\hline $\begin{array}{l}\text { Inadequate designers' H\&S knowledge of construction } \\
\text { activities }\end{array}$ & 10.3 & 2.6 & 7.7 & 17.9 & 38.5 & 23.1 & 3.80 & 8 \\
\hline Inadequate reference to $\mathrm{H} \& \mathrm{~S}$ at design stage & 5.4 & 2.7 & 5.4 & 35.1 & 16.2 & 35.1 & 3.80 & 9 \\
\hline $\begin{array}{l}\text { Inadequate Departmental H\&S personnel's H\&S } \\
\text { knowledge of construction activities }\end{array}$ & 7.7 & 2.6 & 12.8 & 25.6 & 12.8 & 38.5 & 3.78 & 10 \\
\hline $\begin{array}{l}\text { Inadequate designers' construction expertise in terms of } \\
\text { the management of } \mathrm{H} \& S \text { expertise }\end{array}$ & 7.9 & 5.3 & 7.9 & 23.7 & 21.1 & 34.2 & 3.77 & 11 \\
\hline Designer initiated variations & 7.7 & 5.1 & 7.7 & 25.6 & 30.8 & 23.1 & 3.64 & 12 \\
\hline Alterations in scope & 7.7 & 5.1 & 10.3 & 30.8 & 15.4 & 30.8 & 3.61 & 13 \\
\hline $\begin{array}{l}\text { Inadequate top management construction expertise in } \\
\text { terms of the management of } \mathrm{H} \& S\end{array}$ & 7.9 & 10.5 & 10.5 & 23.7 & 21.1 & 26.3 & 3.46 & 14 \\
\hline $\begin{array}{l}\text { Inadequate top management } \mathrm{H} \& \mathrm{~S} \text { knowledge of } \\
\text { construction activities }\end{array}$ & 10.3 & 5.1 & 15.4 & 33.3 & 15.4 & 20.5 & 3.34 & 15 \\
\hline Client initiated variations & 7.7 & 2.6 & 20.5 & 33.3 & 17.9 & 17.9 & 3.31 & 16 \\
\hline
\end{tabular}

Table 4 indicates the extent to which factors contribute to exposure to hazards on construction sites in terms of percentage repsonses to a scale of 1 (minor) to 5 (major), and a MS ranging between 1.00 and 5.00.

It is notable that all the MSs are above the midpoint score of 3.00, which indicates that in general the respondents can be deemed to perceive all factors contribute to exposure to hazards on construction sites.

It is notable that no MSs are $>4.20 \leq 5.00$ - aspects contribute between a near major to major / major extent to exposure to hazards on construction sites. 
However, all the MSs are $>3.40 \leq 4.20$, which indicates the aspects contribute between some extent to a near major / near major extent. The aspects ranked in the top five, and which are within a range of 0.05, are 'inadequate awareness', 'inadequate training', 'inadequate H\&S management', 'inadequate H\&S supervision', and 'inadequate H\&S expertise'. These are followed by 'inadequate H\&S knowledge', 'inadequate H\&S culture', 'inadequate PPE programmes', 'inadequate H\&S experience', and 'inadequate health promotion'.

Table 4. Extent to which factors contribute to exposure to hazards on construction sites.

\begin{tabular}{|c|c|c|c|c|c|c|c|c|}
\hline \multirow{3}{*}{ Factor } & \multicolumn{6}{|c|}{ Response (\%) } & \multirow{3}{*}{ MS } & \multirow{3}{*}{ Rank } \\
\hline & \multirow{2}{*}{$\begin{array}{l}\text { Un- } \\
\text { sure }\end{array}$} & \multicolumn{5}{|c|}{............Major } & & \\
\hline & & 1 & 2 & 3 & 4 & 5 & & \\
\hline Inadequate awareness & 0.0 & 0.0 & 7.7 & 33.3 & 38.5 & 20.5 & 3.72 & 1 \\
\hline Inadequate training & 0.0 & 0.0 & 15.4 & 28.2 & 25.6 & 30.8 & 3.72 & 2 \\
\hline Inadequate $\mathrm{H} \& \mathrm{~S}$ management & 0.0 & 0.0 & 12.8 & 25.6 & 41.0 & 20.5 & 3.69 & 3 \\
\hline Inadequate H\&S supervision & 0.0 & 2.6 & 10.3 & 30.8 & 28.2 & 28.2 & 3.69 & 4 \\
\hline Inadequate H\&S expertise & 0.0 & 0.0 & 7.7 & 41.0 & 28.2 & 23.1 & 3.67 & 5 \\
\hline Inadequate H\&S knowledge & 0.0 & 2.6 & 12.8 & 35.9 & 17.9 & 30.8 & 3.62 & 6 \\
\hline Inadequate H\&S culture & 0.0 & 5.3 & 7.9 & 36.8 & 23.7 & 26.3 & 3.58 & 7 \\
\hline Inadequate PPE programmes & 0.0 & 0.0 & 20.5 & 28.2 & 25.6 & 25.6 & 3.56 & 8 \\
\hline Inadequate $\mathrm{H} \& \mathrm{~S}$ experience & 0.0 & 2.6 & 12.8 & 41.0 & 17.9 & 25.6 & 3.51 & 9 \\
\hline Inadequate health promotion & 0.0 & 2.6 & 15.4 & 38.5 & 20.5 & 23.1 & 3.46 & 10 \\
\hline
\end{tabular}

Table 5 presents the frequency at which factors are the cause of construction accidents in terms of percentage responses to a frequency range never to always, and MSs ranging between 1.00 and 5.00.

It is notable that 20 / 24 (83.3\%) MSs are > 3.00, which indicates that in general, respondents can be deemed to perceive these factors are frequently the cause of construction accidents, as opposed to infrequently.

It is notable that none of the causes' MSs falls within the range $>4.20 \leq 5.00$ - between often to always / always.

12 / 24 (50.0\%) MSs are $>3.40 \leq 4.20$, which indicates the factors can be deemed to be the causes of accidents between sometimes to often / often - 'employee negligence' is ranked first, followed by 'unsafe acts'; 'unskilled workers'; 'unsafe conditions', 'non-compliance with H\&S', 'inadequate H\&S training'; 'poor working platforms', 'inadequate worker participation', 'poor housekeeping', 'non-compliance to SOPs', 'noncompliance to SWPs', and 'inadequate monitoring of construction activities relative to the H\&S plan'.

The remaining 12 / 24 (50.0\%) MSs are $>2.60 \leq 3.40$, which indicates the factors can be deemed to be the causes of accidents between rarely to sometimes / sometimes. 8 / 12 (66.7\%) of the factors' MSs fall within the upper part of the range, namely $>3.00 \leq 3.40$ - 'inadequate PPE', 'inadequate H\&S management', 'inadequate risk management', 'inadequate H\&S supervision', 'inadequate maintenance of plant and equipment', 'inadequate monitoring of construction activities relative to design HIRAs (by designers \& construction project manager/principal agent)', 'inadequate design HIRAs', and 'inadequate construction HIRAs'. The remaining 4 / 12 (33.3\%) factors' MSs fall within the lower part of the range $>2.60 \leq 3.00$ 'inadequate baseline risk assessment', 'poor site layout', 'work factors', and 'extreme temperatures'. 
Table 5. Frequency at which factors are the cause of construction accidents.

\begin{tabular}{|c|c|c|c|c|c|c|c|c|}
\hline \multirow[b]{2}{*}{ Factor } & \multicolumn{6}{|c|}{ Response (\%) } & \multirow[b]{2}{*}{ MS } & \multirow[b]{2}{*}{ Rank } \\
\hline & $\begin{array}{l}\stackrel{0}{5} \\
\stackrel{0}{5} \\
\stackrel{5}{J}\end{array}$ & $\frac{\bar{\phi}}{\grave{d}}$ & 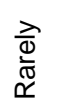 & 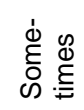 & $\begin{array}{l}\stackrel{\complement}{\Phi} \\
\text { ठँ }\end{array}$ & 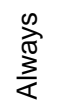 & & \\
\hline Employee negligence & 0.0 & 2.6 & 2.6 & 20.5 & 46.2 & 28.2 & 3.95 & 1 \\
\hline Unsafe acts & 0.0 & 5.1 & 5.1 & 20.5 & 43.6 & 25.6 & 3.79 & 2 \\
\hline Unskilled workers & 2.8 & 5.6 & 11.1 & 25.0 & 30.6 & 25.0 & 3.60 & 3 \\
\hline Unsafe conditions & 0.0 & 5.1 & 12.8 & 33.3 & 15.4 & 33.3 & 3.59 & 4 \\
\hline Non-compliance with $\mathrm{H} \& \mathrm{~S}$ regulations & 5.1 & 2.6 & 5.1 & 41.0 & 30.8 & 15.4 & 3.54 & 5 \\
\hline Inadequate $\mathrm{H} \& \mathrm{~S}$ training & 0.0 & 7.7 & 12.8 & 15.4 & 46.2 & 17.9 & 3.54 & 6 \\
\hline Poor working platforms & 0.0 & 5.1 & 7.7 & 35.9 & 33.3 & 17.9 & 3.51 & 7 \\
\hline Inadequate worker participation & 2.6 & 5.1 & 7.7 & 30.8 & 41.0 & 12.8 & 3.50 & 8 \\
\hline Poor housekeeping & 2.6 & 5.1 & 5.1 & 38.5 & 38.5 & 10.3 & 3.45 & 9 \\
\hline Non-compliance to SOPs & 7.9 & 2.6 & 7.9 & 36.8 & 36.8 & 7.9 & 3.43 & 10 \\
\hline Non-compliance to SWPs & 8.1 & 2.7 & 2.7 & 51.4 & 24.3 & 10.8 & 3.41 & 11 \\
\hline $\begin{array}{l}\text { Inadequate monitoring of construction activities relative to } \\
\text { the H\&S plan }\end{array}$ & 5.1 & 0.0 & 15.4 & 35.9 & 33.3 & 10.3 & 3.41 & 12 \\
\hline Inadequate PPE & 2.6 & 5.1 & 17.9 & 28.2 & 25.6 & 20.5 & 3.39 & 13 \\
\hline Inadequate $\mathrm{H} \& \mathrm{~S}$ management & 2.7 & 2.7 & 18.9 & 29.7 & 29.7 & 16.2 & 3.39 & 14 \\
\hline Inadequate risk management (in general) & 17.9 & 5.1 & 15.4 & 25.6 & 25.6 & 10.3 & 3.25 & 15 \\
\hline Inadequate H\&S supervision & 2.6 & 5.3 & 15.8 & 42.1 & 23.7 & 10.5 & 3.19 & 16 \\
\hline Inadequate maintenance of plant and equipment & 2.6 & 5.3 & 23.7 & 34.2 & 15.8 & 18.4 & 3.19 & 17 \\
\hline $\begin{array}{l}\text { Inadequate monitoring of construction activities relative to } \\
\text { design HIRAs (by designers \& construction project } \\
\text { manager/principal agent) }\end{array}$ & 10.5 & 2.6 & 21.1 & 34.2 & 21.1 & 10.5 & 3.18 & 18 \\
\hline Inadequate design HIRAs & 20.5 & 5.1 & 7.7 & 46.2 & 20.5 & 0.0 & 3.03 & 19 \\
\hline Inadequate construction HIRAs & 20.5 & 5.1 & 15.4 & 33.3 & 23.1 & 2.6 & 3.03 & 20 \\
\hline Inadequate Baseline Risk Assessment & 17.9 & 5.1 & 23.1 & 28.2 & 17.9 & 7.7 & 3.00 & 21 \\
\hline Poor site layout & 0.0 & 2.6 & 28.2 & 46.2 & 23.1 & 0.0 & 2.90 & 22 \\
\hline Work factors & 0.0 & 7.9 & 28.9 & 34.2 & 23.7 & 5.3 & 2.89 & 23 \\
\hline Extreme temperatures & 0.0 & 10.3 & 38.5 & 30.8 & 12.8 & 7.7 & 2.69 & 24 \\
\hline
\end{tabular}

\section{Conclusions}

Given the extent to which a range of thirteen factors contribute to recurring H\&S problems in construction, it can be concluded that: H\&S problems recur; clients, designers, and contractors contribute thereto, and contractor-related factors include general planning and a range of H\&S-related issues. The latter include inadequate management commitment, support, and involvement, financial provision, knowledge, skills, and experience. Given the latter, construction management have a major role to play in the mitigation of recurring $\mathrm{H} \& S$ problems. Furthermore, a multi-stakeholder approach underscored by a multi-faceted contractor approach is required to mitigate recurring H\&S problems.

Given that respondents rated their knowledge regarding eight project management of H\&S aspects as below average, it can be concluded that: their tertiary built environment education is inadequate; they are lacking in terms of related continuing professional development (CPD), and there is limited understanding and appreciation of 'designing for construction $\mathrm{H} \& \mathrm{~S}^{\prime}$.

Given the extent to which sixteen factors contribute to design originated hazards, it can be concluded that: clients, and designers contribute thereto; designers' tertiary built environment education is inadequate; designers are lacking in terms of related CPD, and there is limited understanding and appreciation of 'designing for construction $\mathrm{H} \& \mathrm{~S}$ '. 
Given the extent to which ten factors contribute to exposure to hazards on construction sites, it can be concluded that hazards have their origin in a range of stakeholders, and a range of contractor-related inadequacies contribute thereto.

Given the frequency at which twenty-four factors are the cause of construction accidents, it can be concluded that a range of stakeholders are the origin of the causes, however, the management of contractors has a predominating role to play, especially in terms of $\mathrm{H} \& \mathrm{~S}$ training and worker participation in H\&S.

\section{Recommendations}

H\&S awareness should be maintained at industry, industry sector, organisation, and project level among all stakeholders. Furthermore, H\&S should be a value on all projects, which implies that it is addressed from Stage 1, included in the project charter, addressed during CPMs' meetings with clients, designers, QSs, and contractors, and during project progress meetings. The management of all stakeholders should be committed to H\&S, become involved therein, and support H\&S endeavours.

CPMs should adopt a multi-stakeholder approach in terms of the project management of H\&S throughout all six stages of projects to mitigate recurring H\&S problems, and ideally, should evolve an integrated multistakeholder project H\&S plan. HIRA should be a hallmark of projects commencing with the client BRA, complemented by design HIRA, and followed by construction HIRA. Planning by all stakeholders in general is important to ensure that H\&S is integrated into the design, procurement, and construction processes.

Construction H\&S should be embedded in all tertiary built environment education, and professional association and / or statutory council accreditation panels should assess the status quo. Professional association and statutory councils should promote, and preferably, deliver H\&S-related CPD.

\section{References}

[1] Construction Industry Development Board (cidb), Construction Health \& Safety in South Africa Status \& Recommendations, cidb, Pretoria, 2009.

[2] South African Council for the Project and Construction Management Professions (SACPCMP), Construction Project Manager: Identification of Work and Scope of Services for Construction Project Managers Registered in Terms of the Project and Construction Management Professions, Act No. 48 of 2000, SACPCMP, Johannesburg, 2006.

[3] Republic of South Africa, No. R. 84 Occupational Health and Safety Act, 1993 Construction Regulations 2014. Government Gazette No. 37305, Pretoria, 2014.

[4] Department of Education, Employment and Workplace Relations, The Model Client Framework The Model Client: PromotingSafe Construction, Commonwealth of Australia, Canberra, 2008.

[5] Smallwood, J.J., "The Role of Construction Project Managers (CPM) in Construction Health and Safety (H\&S)", Proceedings the International Conference on Construction Project Management and Construction Engineering (iCCPMCE 2018), Sydney, Australia, 03-06 December, pp. 140-145, 2018.

[6] Haslam, R.A., Hide, S.A., Gibb, A.G.F., Gyi, D.E., Pavitt, T., Atkinson, S. \& Duff. A.R. "Contributing factors in construction”, Applied Ergonomics, vol 36, pp. 401-415, 2005. https://doi.org/10.1016/j.apergo.2004.12.002. 